\title{
A case of mass occurrence of Prorocentrum minimum in the Kiel Fjord
}

\author{
B. Kimor', A. G. Moigis, V. Dohms \& C. Stienen \\ Instifut für Meereskunde an der Universität Kiel, Düsternbrooker Weg 20, D-2300 Kiel, Federal Republic of Germany
}

\begin{abstract}
A case of mass development of the potentially toxic dinoflagellate Prorocentrum minimum was recorded in the inner reaches of the Kiel Fjord in July/August 1983. Although this species has been sporadically recorded at a number of locations in Norwegian, Danish and Swedish coastal waters, this is the first record of a massive bloom in this part of the Baltic Sea. The bloom seems to have been favoured by relatively high temperatures, high insolation and calm weather conditions prevailing at the time. The dinoflagellate did not prove toxic either to mussel beds in adjoining areas of the Kiel Bight, affected by the bloom, or to other test organisms in the laboratory.
\end{abstract}

\section{INTRODUCTION}

During the months of July and August 1983 a conspicuous bloom was observed in the harbor area of the Kiel Fjord. Microscopic examination of the water revealed the presence of large numbers of a Prorocentrum species later identified, according to Dodge (1975, 1982), as P. minimum (Pavillard) Schiller.

The dinoflagellate has a heart-shaped form, is 18 to $20 \mu \mathrm{m}$ long and 15 to $16 \mu \mathrm{m}$ wide, with a slight depression at its wider end. The surface of the plates is covered with minute spines (Fig. 1a, b, c). It moves about swiftly in the water with an oscillating movement and alternate turning about its long axis.

In view of the close affinity of this species to Prorocentrum triangulatum and $P$. mariae-lebouriae, considered as morphotypes of the same species (Dodge 1975, Tangen 1980), and its characteristic shape, the taxonomic position of this bloom-forming dinoflagellate was re-examined and established for reference purposes as $P$, minimum (Pavillard) Schiller var, triangulatum (Hulbert ex Adachi) (Elbrächter, pers. comm.). However, for practical purposes the name $P$. minimum will be used throughout this paper.

There are to date no records of mass occurrence of Prorocentrum minimum in the Baltic Sea. Pankow (1976) refers only to $P$. micans and 3 species of Exuviella including E. baltica (all of which are now

\footnotetext{
'Present address: Technion - Israel Institute of Technology, Haifa 32000, Israel
}

included in the genus Prorocentrum) as the Baltic representatives of the genus. However, $P$. minimum has now been reported, albeit in relatively low concentrations (about 30 cells $\mathrm{ml}^{-1}$ ), near Bornholm, Denmark (Baltic Marine Environment Protection Commission 1982).

The same species was, however, described as causing brown water due to its mass development together with other dinoflagellates in Oslo Fjord during August to September 1979 (Tangen 1980) and as potentially toxic to humans through shellfish poisoning (Okaichi \& Imatomi 1979, Tangen 1983, Langeland et al. 1984). It was also reported that this organism appeared for the first time (at about the same time of the year) on the west coast of Sweden (Granéli \& Granéli 1982) and also in the Kattegat (Edler et al. 1982, Pingree at al. 1982, Nielsen \& Frtebjerg-Nielsen 1983, Pedersen 1983, Granéli et al. 1984).

In view of the unusual occurrence of this bloom in the Kiel Fjord, and its potential danger due to the accumulation of algal toxins by edible shellfish, it was decided to monitor the occurrence of Prorocentrum minimum on a day-to-day basis during the weeks following its initial detection.

\section{METHODS}

Unconcentrated water samples preserved in Lugol's iodine were used for determining the numerical abundance of Prorocentrum minimum in the surface 

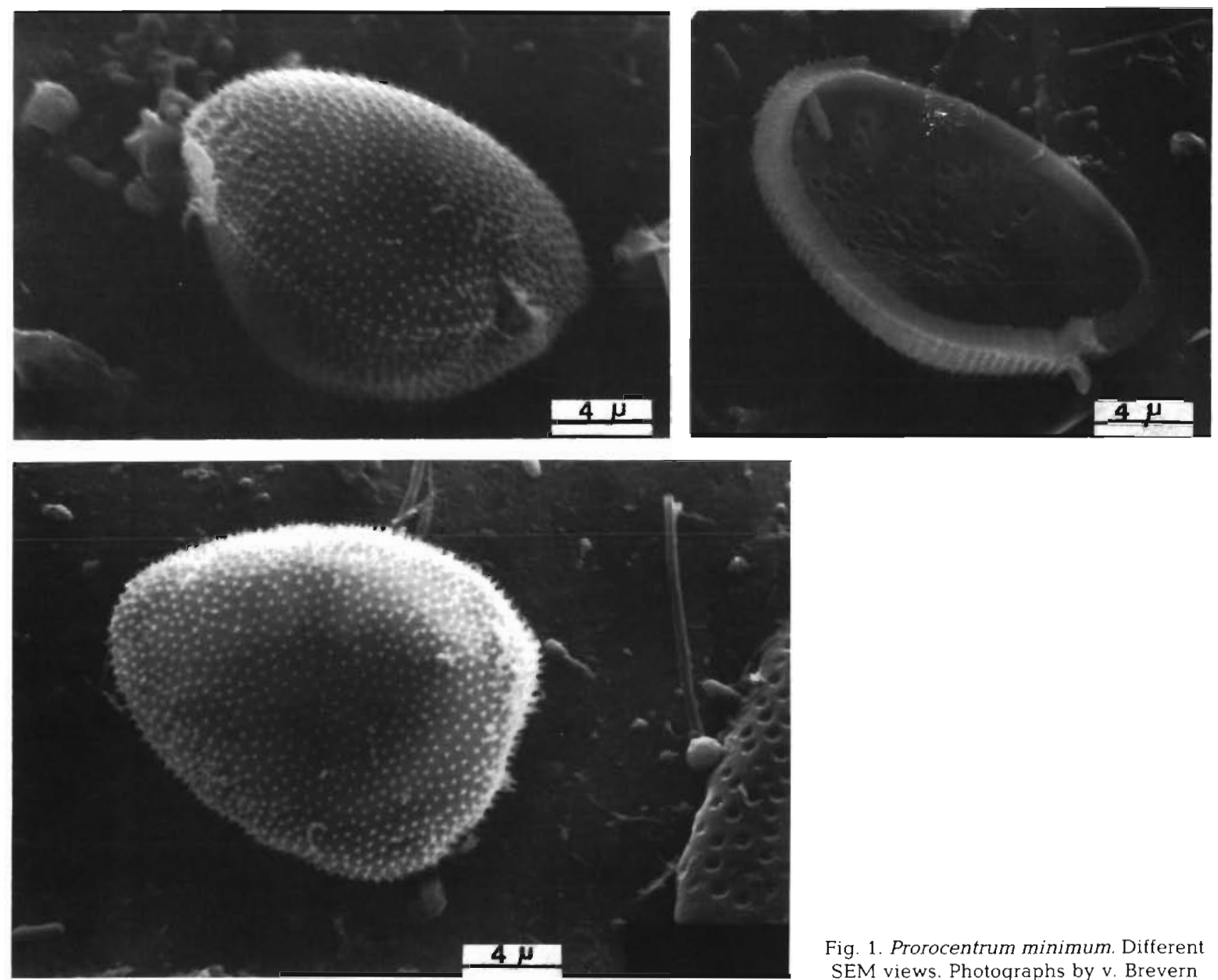

Fig. 1. Prorocentrum minimum. Different SEM views. Photographs by v. Brevern

layer by the Utermöhl technique (1958). On one occasion, towards the end of the monitoring period, the vertical distribution of $P$. minimum near the pier of the Institut für Meereskunde, Kiel (Stn 2 in Fig. 2) was determined in a similar fashion to a depth of $5 \mathrm{~m}$. In addition, plankton samples were collected here with a small $40 \mu m$ mesh net from the water surface for determination of the most common accompanying larger species.

Sampling operations and observations on some environmental parameters were carried out between noon and $1500 \mathrm{~h}$. Salinity and temperature were measured by a Switchgear instrument; wind velocity and direction as well as light intensity data were obtained from the Marine Meteorology Department of the Institut für Meereskunde, Kiel. On 2 longitudinal transects of the Kiel Fjord (Fig, $4 \mathrm{a}$, b) carried out on 25 July and 16 August, counts were made of Prorocentrum minimum, and essential nutrient levels (ammonia, nit- rite, nitrate, phosphate) and total phosphorus were determined according to Grasshoff (1976).

During the above transects, 2 samples were taken at each of the 8 stations: one as close as possible to the sea floor (approximately 0.7 to $1.2 \mathrm{~m}$ above the bottom) and the second combined from 2 to 3 levels in the mixed layer close to the surtace. Chlorophyll a determination followed the UNESCO (1966) recommendations with modification by Derenbach (1969).

Toxicity tests of Prorocentrum minimum were carried out on crabs and mice with methanol extracts as recommended by Okaichi \& Imatomi (1979).

\section{RESULTS AND DISCUSSION}

Prorocentrum minimum appeared for the first time between 11 July (no counts of the organism) and 27 July, 1983 (first quantitative estimation). The weather 


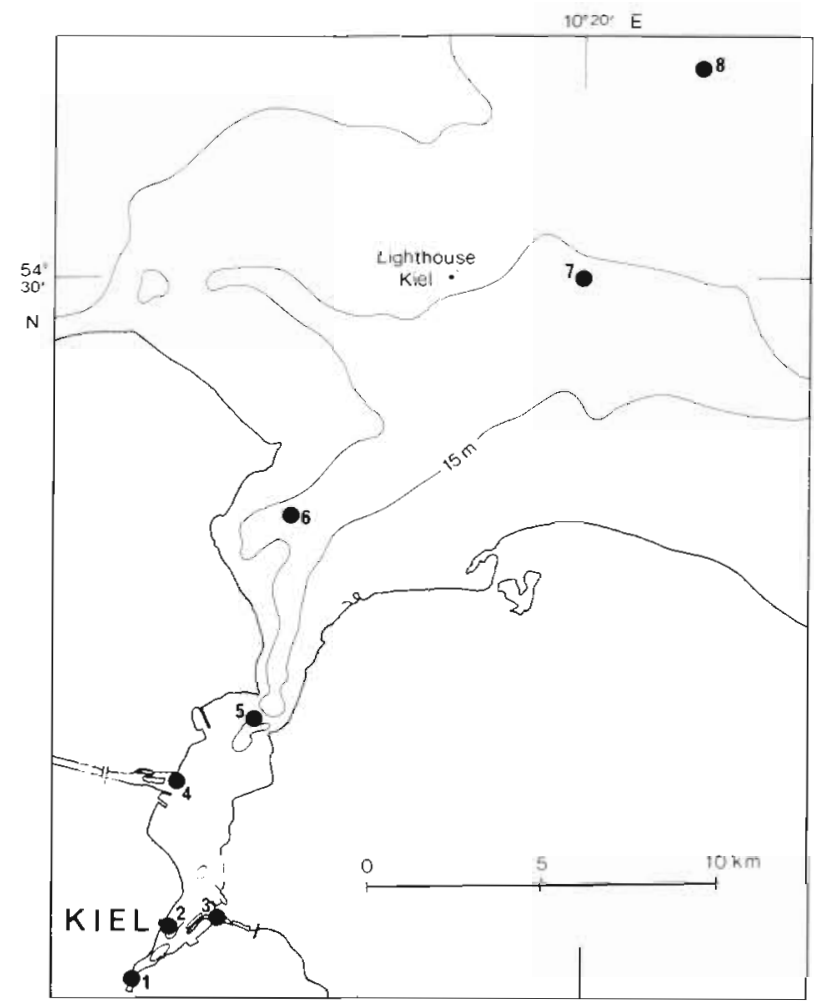

Fig. 2. Location of the sampling stations on 25 July and 16 August 1983. Stn 2 and 3 were at the Institute Pier and in the Schwentine River Estuary, respectively

conditions during these initial $17 \mathrm{~d}$ were very calm, and insolation reached its maximum intensity for the whole investigation period. During the same period, 6 days exhibited winds from $000^{\circ}$ to $090^{\circ}$, considered as being onshore with regard to the Kiel Fjord. On these days mean wind speed was as low as $3.7 \mathrm{~m} \mathrm{~s}^{-1}$ and insolation reached a mean value of $2.5 \pm 0.8 \times 10^{4} \mathrm{KJ}$ $\mathrm{m}^{-2}$. On the other hand, only 3 days exhibited off shore winds $\left(180^{\circ}\right.$ to $\left.270^{\circ}\right)$ with an average speed of $4.6 \mathrm{~m} \mathrm{~s}^{-1}$ and an insolation of $1.9 \pm 0.6 \times 10^{4} \mathrm{KJ} \mathrm{m}^{-2}$. Further information is given in Table 1 . Due to these conditions, water exchange between Kiel Fjord and Kiel Bight was largely inhibited, while phytoplankton growth was enhanced by the high light energy supply.

The results of the surface cell counts during the time of monitoring showed 2 distinct peaks, one during the last days of July and the second toward the end of August (Fig 3, Table 2). An indication of the vertical distribution of Prorocentrum minimum in the Kiel Fjord during the bloom period is given in Table 3. It can be seen that the bloom occurred in the upper $2 \mathrm{~m}$ followed by a sharp drop further down. Similar results have been obtained in regard to $P$. micans in a sea area west of the Island of Sylt (Wandschneider 1979). Maximum cell concentration, recorded on 20 August 1983, was $31.2 \times 10^{6} \mathrm{l}^{-1}$. An average carbon content of 290 pg cell ${ }^{-1}$ for $P$. minimum can be estimated using the recommendations of the BMB (Edler 1979).

Salinity and temperature determinations (Table 1 , Fig. $3 \& 4 a, b)$ were found to be in the same range as those of Tangen's records from the inner and outer reaches of Oslo Fjord for the same time of the year (Tangen 1980). Prevailing winds, mainly in a northerly direction, never exceeded $7.5 \mathrm{~m} \mathrm{~s}^{-1}$.

The longitudinal transects of the Kiel Fjord showed high cell abundance of Prorocentrum minimum only in the inner part $\left(16.591 \times 10^{6} 1^{-1}\right.$ on 25 July, 1983 at Stn 1; Table 2), where higher nutrient levels were observed (Fig. 4a). On 11 August the oxygen-saturation at the surface was $113 \%$ and the $\mathrm{pH}$ was 9.1 (Nellen, pers. comm.), indicating the high production of the bloom. Chlorophyll data from the sampling site (Stn 2) and the contribution of cells $<20 \mu \mathrm{m}$ recorded on 25 July, 1983 during the initial stages of the bloom showed unusually high levels: $42.2 \mu \mathrm{g}^{-1}$ total chlorophyll a content of which $31.3 \mu \mathrm{g} \mathrm{l}^{-1}$ was contained in the organisms $<20 \mu \mathrm{m}$. This also appeared at Stn 1 and 3 to 5, where the same proportion of chlorophyll a was seen in the $<20 \mu \mathrm{m}$ fraction during the same transect.

According to Smetacek \& Hendrikson (1979), a phytoplankton carbon:chl a ratio of $100 \pm 20: 1$ could be assumed for dinoflagellate summer populations. Although there are some uncertainties in this assessment, the chl a concentration of $42.2 \mu \mathrm{g} \mathrm{l}^{-1}$ on $25 \mathrm{July}$ indicates a density of some $15 \times 10^{6}$ cells $\mathrm{l}^{-1}$. Obviously not all of them were Prorocentrum minimum. Thus it can be assumed that the observation period missed the real starting point of the bloom by at least 2 or $3 \mathrm{~d}$. This is supported by the fact that the chl a concentration on 25 July at Stn 1 (Hörn) was more than $97 \mu \mathrm{g} \mathrm{l}^{-1}$, the highest value recorded in the Kiel Fjord area.

The phytoplankton composition throughout the bloom remained fairly constant with a number of accompanying species consistently present. Among these, Prorocentrum micans, Ceratium tripos, Cerataulina pelagica and Dinophysis acuminata were always present. On 26 August Chaetoceros socialis was particularly conspicuous. In most of the plankton samples examined from Stn 2 (Pier of Institut für Meereskunde), a number of freshwater plankton organisms were recorded. These included a summer form of Ceratium hirundinella with a third antapical horn and numerous rotifers, which evidently reached the Fjord waters via runoff from the Schwentine River (Stn 3 in Fig. 2).

The massive red tide caused by Prorocentrum minimum in the Kiel Fjord in late summer 1983 constitutes a new record for this part of the Baltic Sea. Since its first occurrence as a cause of brown water in Oslo 
Table 1. Density of Prorocentrum minimum, salinity and temperature (at $1200 \mathrm{~h}$ ), wind speed and direction (mean of light period) and light intensity (integrated for the light period) at Stn 2 (pier of the Institute)

\begin{tabular}{|c|c|c|c|c|c|c|c|}
\hline Date & $\begin{array}{l}\text { Cell density } \\
\qquad 10^{6} 1^{-1}\end{array}$ & $\begin{array}{l}\mathrm{S} \\
\%\end{array}$ & $\begin{array}{l}\mathrm{T} \\
{ }^{\circ} \mathrm{C}\end{array}$ & $\begin{array}{c}\text { Onshore } \\
\mathrm{m} \mathrm{s}^{-1}\end{array}$ & $\begin{array}{c}\text { Wind } \\
\text { Parallel } \\
\mathrm{m} \mathrm{s}^{-1}\end{array}$ & $\begin{array}{c}\text { Offshore } \\
\mathrm{m} \mathrm{s}^{-1}\end{array}$ & $\begin{array}{c}\text { Light } \\
10^{4} \mathrm{KJ} \mathrm{m}^{-2}\end{array}$ \\
\hline $23 \mathrm{Jul}$ & - & - & 20.6 & 2.7 & & & 2.62 \\
\hline $24 \mathrm{Jul}$ & - & - & 21.5 & 4.4 & & & 2.53 \\
\hline $25 \mathrm{Jul}$ & - & - & 22.0 & 5.6 & & & 2.51 \\
\hline $26 \mathrm{Jul}$ & - & - & 22.3 & & 2.7 & & 2.19 \\
\hline $27 \mathrm{Jul}$ & 2.5 & - & 19.1 & & 4.3 & & 1.93 \\
\hline $28 \mathrm{Jul}$ & 16.2 & 14.5 & 23.4 & & 4.6 & & 1.66 \\
\hline $29 \mathrm{Jul}$ & 3.6 & 14.5 & 22.8 & & & 5.6 & 0.68 \\
\hline $30 \mathrm{Jul}$ & 18.3 & 14.8 & 20.8 & & 6.3 & & 2.07 \\
\hline $31 \mathrm{Jul}$ & 5.4 & 14.9 & 21.1 & 2.3 & & & 2.34 \\
\hline 1 Aug & 2.8 & 14.8 & 22.6 & & & 8.1 & 1.37 \\
\hline $2 \mathrm{Aug}$ & 1.1 & 15.7 & 20.4 & & & 6.1 & 1.80 \\
\hline $3 \mathrm{Aug}$ & 3.7 & 14.8 & 19.7 & 4.9 & & & 1.96 \\
\hline 4 Aug & 1.5 & 14.7 & 19.0 & & 3.0 & & 0.49 \\
\hline 5 Aug & 1.2 & 14.5 & 19.5 & 5.9 & & & 1.80 \\
\hline 6 Aug & 3.6 & 14.0 & 19.9 & 3.4 & & & 1.96 \\
\hline 7 Aug & 3.3 & 14.3 & 20.6 & 3.2 & & & 2.09 \\
\hline $8 \mathrm{Aug}$ & 3.2 & 14.1 & 21.4 & 3.3 & & & 2.07 \\
\hline 9 Aug & 0.2 & 14.2 & 21.5 & 3.7 & & & 2.28 \\
\hline $10 \mathrm{Aug}$ & 2.1 & 14.2 & 21.4 & 3.2 & & & 2.33 \\
\hline 11 Aug & 3.6 & 14.4 & 21.2 & & 3.3 & & 2.32 \\
\hline 12 Aug & 2.2 & 14.4 & 21.0 & & & 5.2 & 0.90 \\
\hline 13 Aug & - & - & - & 5.8 & & & 2.07 \\
\hline 14 Aug & - & - & - & & 3.9 & & 1.57 \\
\hline $15 \mathrm{Aug}$ & 0.8 & 15.1 & 19.8 & & & 4.3 & 2.23 \\
\hline 16 Aug & 0.4 & 15.3 & 18.0 & & & 5.8 & 1.80 \\
\hline 17 Aug & 0.9 & 15.1 & 19.6 & & 2.2 & & 1.15 \\
\hline 18 Aug & 0.4 & 15.1 & 19.0 & 4.6 & & & 1.17 \\
\hline 19 Aug & 2.3 & 15.1 & 19.8 & 4.8 & & & 1.60 \\
\hline 20 Aug & 31.2 & 14.5 & 20.4 & & 4.0 & & 1.69 \\
\hline $21 \mathrm{Aug}$ & 4.0 & 15.1 & 20.4 & 5.5 & & & 1.85 \\
\hline $22 \mathrm{Aug}$ & 0.4 & 15.1 & 21.5 & 2.2 & & & 1.34 \\
\hline 23 Aug & 2.8 & 15.5 & 20.5 & & & 2.6 & 1.68 \\
\hline 24 Aug & 3.4 & 15.1 & 21.9 & 3.3 & & & 1.59 \\
\hline 25 Aug & 9.2 & 15.0 & 21.4 & 3.2 & & & 1.15 \\
\hline \multirow[t]{4}{*}{$26 \mathrm{Aug}$} & 3.2 & 15.3 & 20.4 & 3.0 & & & 1.97 \\
\hline & & & & $\mathrm{n}=19$ & 9 & 7 & \\
\hline & & & & $\bar{x}=3.95$ & 3.81 & 5.49 & \\
\hline & & & & $\mathrm{SD}=1.20$ & 1.22 & 1.69 & \\
\hline
\end{tabular}

Fjord in 1979 (Tangen 1980), $P$. minimum has expanded its area of distribution in subsequent years through the Skagerrak and Kattegat into Swedish and Danish coastal waters, as reported above by several investigators.

A combination of physical factors appears to have been responsible for the development of the bloom at that particular time. The relatively high temperatures of the surface water in the Fjord (20 to $22^{\circ} \mathrm{C}$ ), coupled with high light intensity and moderate winds for most of the duration of the bloom, may all or in part have been contributing factors to the development of the bloom. These factors have been suggested as the main causes of red tides in various marine environments (Lee 1980). The last factor (wind) as a cell concentrat- ing mechanism in surface waters of the inner reaches of the Kiel Fjord may have been the most important of the three, due to its speed and direction and the special configuration of this water body.

While the initiation of the bloom seems to be supported by favourable meteorological conditions, its maintenance is due to the permanent availability of nutrients. Both phosphate-P and nitrogen compounds are available in the mixed layer of the Kiel Fjord at considerably higher levels than in Kiel Bight. Nitrate and ammonia supplied nitrogen during the initial phase of the bloom, while ammonia was available towards the end in unusually high amounts, indicating a high remineralization rate. Thus the onset of the bloom could be considered as being balanced between 
Fig. 3. Hydrological and meteorological data, and cell counts of Prorocentrum minimum. Light intensity, wind speed and direction, salinity, temperature ( 3 arrows indicate data off top of scale, see Table 1), tide mark (zero calibrated to sea level), abundance of $P$. minimum (dotted lines indicate no data available)

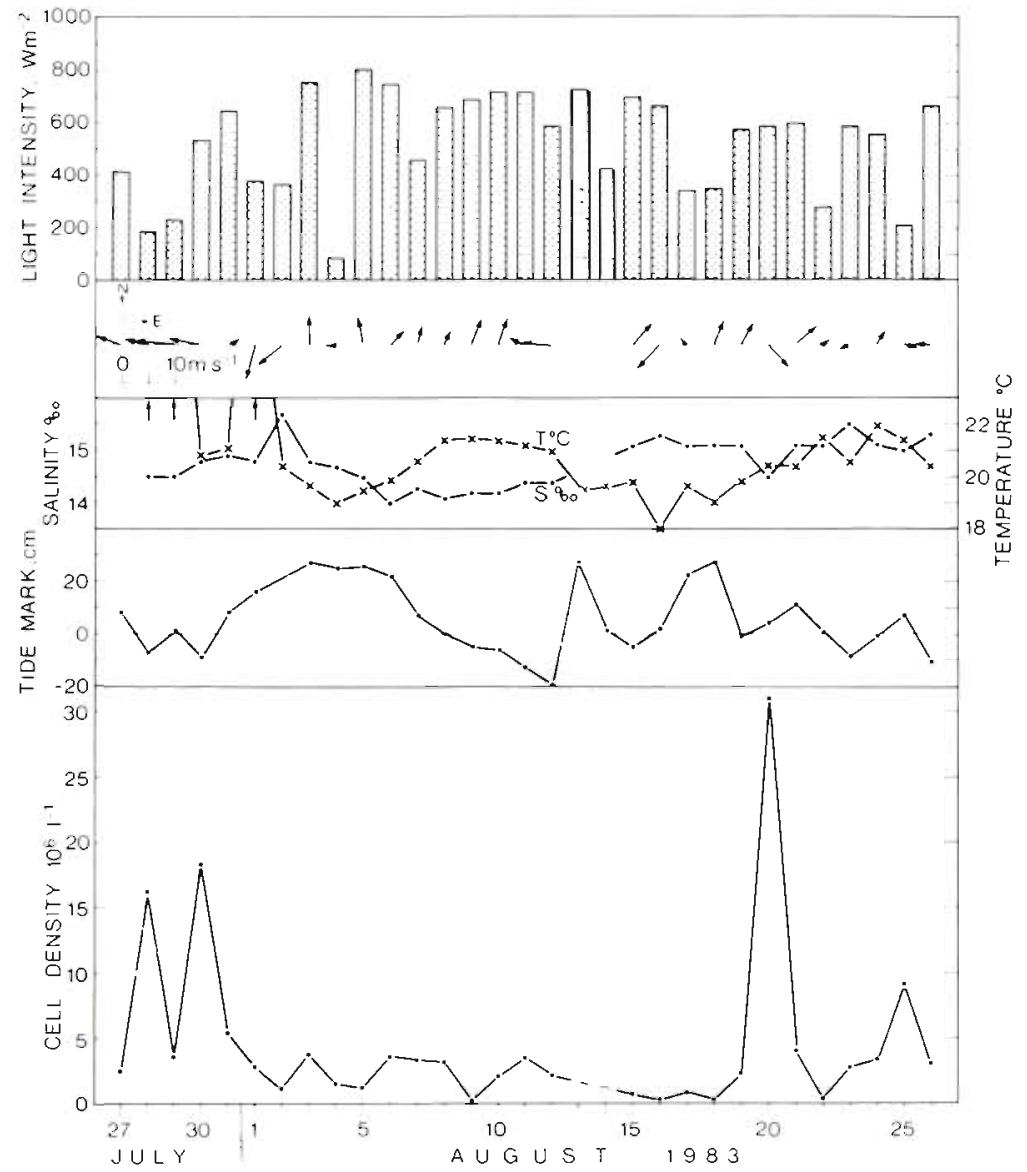

Table 2. Prorocentrum minimum. Surface density $\left(10^{6}\right.$ cells $\left.1^{-1}\right)$ at Stn 1 to 8 during the transects

\begin{tabular}{|ccc|}
\hline Stations & July 25 & August 16 \\
\hline 1 & 16.591 & 0.450 \\
2 & 9.609 & 1.202 \\
3 & 1.162 & 2.504 \\
4 & 5.698 & 0.069 \\
5 & 0.566 & 0.138 \\
6 & 0.465 & 0.133 \\
7 & 0.813 & 0.013 \\
8 & 0.026 & - \\
\hline
\end{tabular}

Table 3. Prorocentrum minimum. Depth distribution $\left(10^{6}\right.$ cells $\mathrm{I}^{-1}$ ) at $\operatorname{Stn} 2$ at noon on August 26, 1983

\begin{tabular}{cc|}
\hline Depth, $\mathrm{m}$ & Distribution \\
\hline 0 & 3.25 \\
1 & 3.06 \\
2 & 2.04 \\
3 & 0.49 \\
4 & 0.43 \\
5 & 0.77 \\
\hline
\end{tabular}

new and regenerated production, while regeneration dominated later, although nitrate values increased little in August. Phosphate-P and nitrate- $\mathrm{N}$ were introduced into Kiel Fjord from 2 different sources: while phosphate is released in considerable amounts from anoxic sediments, nitrate is delivered by river run-off and originates from agricultural fertilizers. Steidinger (1975) pointed to the support of a bloom by continuous availability of nutrients as the second stage in the life cycle of red tides. Although her statement referred to toxic blooms, it is valid also for the present record.

There is to date little information from other areas regarding the impact of environmental factors directly related to this particular species of dinoflagellate. The general euryhaline and eurythermal characteristics of this species (Birnhak \& Farrow 1965, Campbell 1973, Tangen 1980) would both provide an explanation for its eastward expansion into the Baltic Sea. However, pertinent information is available in regard to other species of the genus Prorocentrum. Thus, Braarud \& Heimdal (1970) recorded the presence of $P$. micans as the predominant species at Drobak, at the entrance to the highly polluted waters of Oslo Fjord, with a concentration of $20 \times 10^{6}$ cells $1^{-1}$. Fudge (1977) found a positive correlation between the cell density of $P$. 

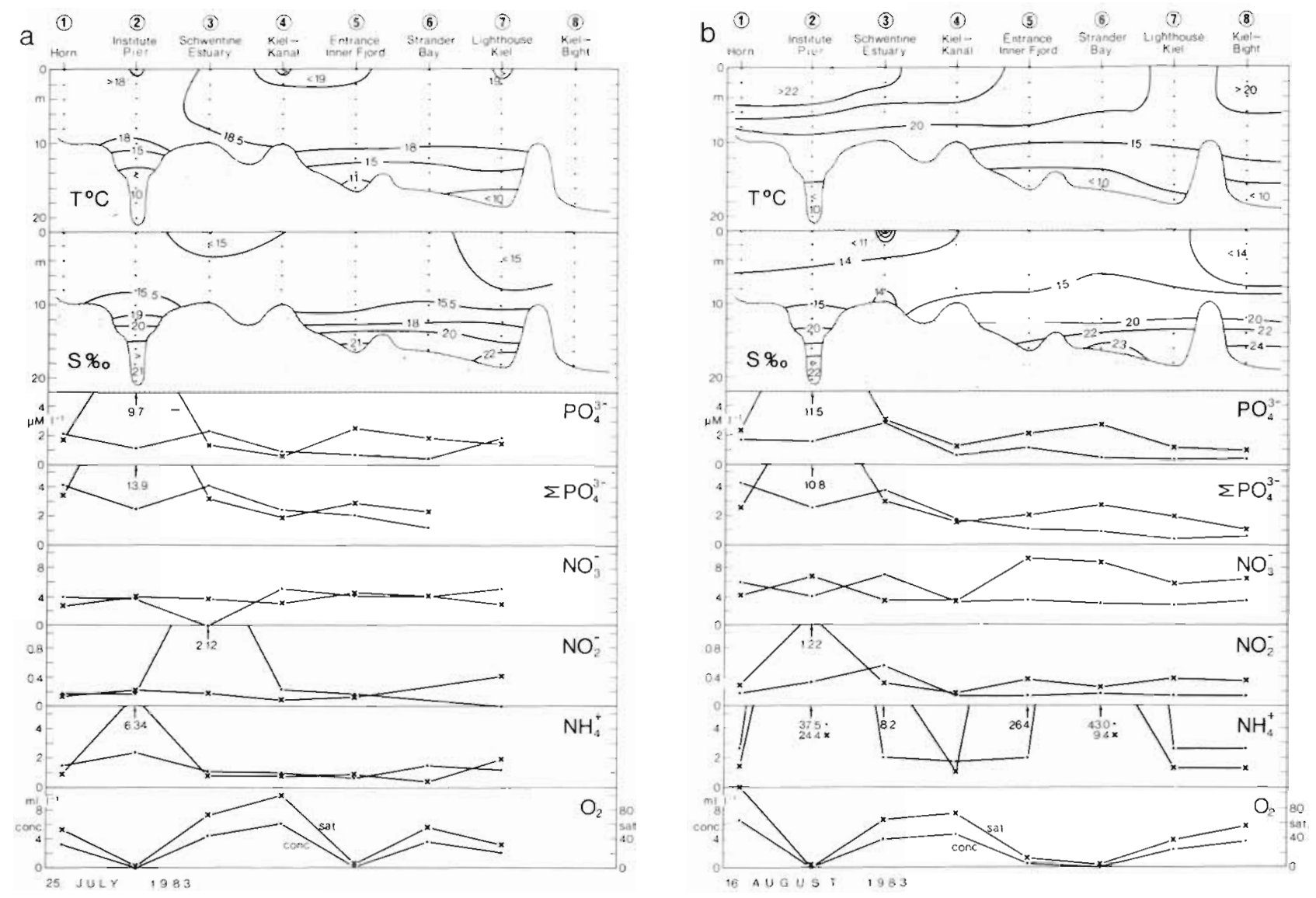

Fig. 4. Environmental parameters in transects on (a) 25 July and (b) 16 August 1983. Temperature and salinity versus depth. Nutrients and total phosphate in $\mu \mathrm{M} \mathrm{l}^{-1} ;(x)$ sampling depth near the bottom, (.) representative sample of the mixed layer.

Oxygen samples taken close to the bottom, given as concentration and as \% of full saturation

triestinum and the surface temperature in Marsamxetto Harbour, Malta, during May 1970. At that time, the surface temperature during the period of red water ranged from $20.2^{\circ}$ to $22.6^{\circ} \mathrm{C}$, with the highest values recorded in the surface waters and gradually decreasing with depth. A close relation was also found by the same investigator between cell numbers and insolation.

Regarding the origin of the Prorocentrum minimum bloom in the Kiel Fjord, the following suggestions may be made: a southward subsurface process of advection might originate from the Skagerrak, similar to the transport of the closely related morphotype P. mariae lebouriae from the southern Chesapeake Bay to the northern bay, where it upwells and forms red tides (Tyler \& Seliger 1981). Such a possibility could be envisaged in view of the fact that subsurface

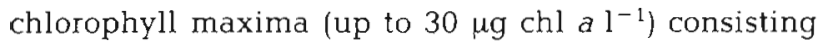
largely of $P$. minimum have been reported from the Skagerrak area (Pingree et al. 1982) and from the surface waters at the main sampling station in the Kiel Fjord (Stn 2) during the initial stages of the bloom $\left(42.2 \mu \mathrm{g} \mathrm{chl} \mathrm{a} \mathrm{l}^{-1}\right)$.
A second suggestion that might be considered is that the seed population for Prorocentrum minimum red tide in the Kiel Fjord might originate from the resting cysts of this species which became resuspended due to environmental factors, thus creating a motile population capable of active asexual divisions. This seems to be the case of many neritic and estuarine bloom species producing resting cysts (Steidinger \& Haddad 1981).

Both these suggestions, which are not necessarily unrelated, would have to be substantiated by longterm monitoring of the waters at discrete depths for analysis of phytoplankton species in the light of available data on the hydrography of the region and the dynamics of phytoplankton bloom patches in the Skagerrak, Kattegat and Bornholm Basin (Astheimer 1983).

There was no evidence of toxicity of the bloom on the basis of laboratory tests carried out on crabs, mice and fish, although not on mussels, which are known to accumulate the toxin venerupin produced by Prorocentrum minimum. Due to the fact that the presence of $P$. minimum was also recorded on a qualitative basis in 
the adjoining Schlei and Flensburg Fjord waters, where mussel beds are located, the Health Authorities in these areas were alerted to be on the look-out for any ill effects to humans due to this potentially toxic dinoflagellate, through consumption of the mussels. This danger, however, did not materialize.

Acknowledgements. The authors wish to express their thanks and appreciation to the following colleagues for their help and assistance in various ways during the progress of this investigation and the preparation of the manuscript: E. Bauerfeind, J. R. Beers, L. Beress, M. Elbrachter, J. Lenz, W. Nellen, F. M. H. Reid, K. Uhlig, B. Zeitzschel.

\section{LITERATURE CITED}

Astheimer, H. (1983). Phytoplankton spring bloom patches in the Skagerrak, Kattegat and Bornholm Basin. In: Sündermann, J., Lenz, W. (ed.) North Sea dynamics. SpringerVerlag, Berlin, p. 611-631

Baltic Marine Environment Protection Commission (1982). Second biological intercalibration workshop, Ronne, 17-20 August 1982. Baltic Sea Environment Proceedings No. 9

Birnhak, B., Farrow, W. (1965). Exuviella mariae-lebouriae n.sp., Parke and Ballantine. Fl. Bd. Conserv., Mar. Lab., Leaflet Ser., Plankton. 1 (10): 1-4

Braarud, T., Heimdal, B. R. (1970). Brown water on the Norwegian coast in autumn 1966. Nytt Mag. Bot. 17 (2): 91-97

Campbell, P. H. (1973). Studies on brackish water phytoplankton. Sea Grant Publ. UNC-5G-73-07: 118-119

Derenbach, J. (1969). Zur Homogenisation des Phytoplanktons für die Chlorophyllbestimmung. Kieler Meeresforsch. 25: $166-171$

Dodge, J. D. (1975). The Prorocentrales (Dinophyceae) II Revision of the taxonomy within the genus Prorocentrum. Bot. J. Linn. Soc. 2: 103-125

Dodge, J. D. (1982). Marine dinoflagellates of the British Isles. Her Majesty's Stationary Office, London

Edler, L. ed. (1979). Recommendations on methods for marine biological studies in the Baltic Sea. Phytoplankton and chlorophyll. Baltic Marine Biologists Publ. (5)

Edler, L., Exrtebjerg-Nielsen, G., Graneli, E. (1982). Exceptional plankton blooms in the entrance to the Baltic Sea, the Kattegat and Belt Sea area. J. Cons. perm. int. Explor. Mer, C.M./2:20: 1-6 (mimeo)

Fudge, H. (1977). The red tides of Malta. Mar. Biol. 39. 381-386

Granéli, E., Granéli, W. (1982). Eutrophication and dinoflagellate blooms in Swedish coastal waters. Possible causes and countermeasures. Paper presented at the Int. Symp. on Utilization of Coastal Ecosystems: Planning,
Pollution and Productivity, Rio Grande del Sol, Brazil, 22-27 Nov., 1982 (mimeo)

Granéli, E., Edler, L., Graneli, W., Fleisher, S. (1984). Possible causes of changes in the fluctuation and succession of phytoplankton leading to red tide on the Swedish west coast. In: Boutler, J. (ed.) 17th European Mar. Biol. Symp., Brest, France, 1982. Oceanologia Acta, vol. spéc.

Grasshoff, K. (1976). Methods of seawater analysis. Verlag Chemie, Weinheim

Langeland, G., Hasselgard, T., Tangen, K., Skulberg, O. M., Hielle, A. (1984). An outbreak of paralytic shellfish poisoning in western Norway. Sarsia 69: 185-193

Lee, R. E. (1980). Phycology. Cambridge University Press

Nielsen, A., Ertebjerg-Nielsen, G. (1983). Plankton blooms in Danish waters. Ophelia, Suppl. 3: 181-188

Okaichi, T., Imatomi, Y. (1979). Toxicity of Prorocentrum minimum var. mariae-lebouriae assumed to be a causative agent of short-necked clam poisoning. In: Taylor, D. L., Seliger, H. H. (ed.) Toxic dinoflagellate blooms. Elsevier/ North Holland, New York, p. 385-388

Pankow, H. (1976). Algenflora der Ostsee, Bd. 2. VEB, Jena

Pedersen, S. M. (1983). Udbredelsen af Prorocentrum minimum i Danske flarvande i August 1983. Rapport Til Miljostyrelsens Havforurenings laboratorium. Marine ID, Marine Identification Agency APS, Skodsborg Strandvej 85, 2942 Skodsborg

Pingree, R. D., Holligan, P. M., Mardelli, G. T., Harris, R. P. (1982). Vertical distribution of plankton in the Skagerrak in relation to doming of the seasonal thermocline. Continental Shelf Res. 1; 209-219

Smetacek, V., Hendrikson, P. (1979). Composition of particulate organic matter in Kiel Bight in relation to phytoplankton succession. Oceanologica, Acta 2: 287-298

Steidinger, K. A. (1975). Basic factors influencing red tides In: Lo Cicero, V L. (ed.) Proc. 1st Int. Conf. on Toxic Dinoflagellate Blooms, Nov. 1974, Massachusetts Science and Technology Foundation, p. 153-162

Steidinger, K. A., Haddad, K. (1981). Biologic and hydrographic aspects of red tides. Bioscience 31 (11): 814-820

Tangen, K. (1980). Brunt vann i Oslofjorden i September 1979, forarsaket av den toksiske Prorocentrum minimum og andre dinoflagellater. Blyttia 38: 145-158

Tangen, K. (1983). Shellfish poisoning and the occurrence of potentially toxic dinoflagellates in Norwegian waters. Sarsia 68: 1-7

Tyler, M. A., Seliger, H. A. (1981). Selection for a red tide organism: physiological responses to the physical environment. Limnol. Oceanogr. 26 (2): 310-324

UNESCO (1966). Determination of photosynthetic pigments in the sea water Monographs on Oceanographic Methodology 1: 1-69

Utermöhl, H. (1958). Zur Vervollkommnung der quantitativen Phytoplankton-Methodik. Int. Ass. Theor Appl. Limnol. Commun. 9: 1-38

Wandschneider, K. (1979). Vertical distribution of phytoplankton during investigations of a natural surface film. Mar. Biol. 52: 105-111 